\title{
Increased erythrocyte volume in car repair painters and car mechanics
}

\author{
H Beving, G Tornling, P Olsson
}

\begin{abstract}
The biological effect of occupational long term low level exposure to organic solvents was studied in 17 car repair painters and 28 car mechanics, and compared with a control group consisting of 46 healthy men not exposed to organic solvents. The erythrocyte count (RBC) was significantly decreased for both the painters and the mechanics compared with the control group, and a significant increase in the mean erythrocyte volume (MCV) was seen in painters. The mode in size distribution of the erythrocytes (MAXRBC) was shifted towards larger cell volumes for both painters and mechanics. When data from painters and mechanics were combined, the exposed group showed a significantly reduced erythrocyte count (RBC), an increased mean erythrocyte volume (MVC), and an increased mean platelet volume (MPV) compared with the controls. Exposure measurements in combination with analysis of haematological parameters may be a tool for early detection of cellular changes in the blood caused by exposure to solvents, before the appearance of clinical symptoms.
\end{abstract}

Some of the biological effects of exposure to organic solvents are functional changes of the blood forming organs, the liver, and the central nervous system. ${ }^{1-3}$ Exposure to organic solvents, especially benzene, has been shown to have a deleterious effect on bone marrow. ${ }^{3-5}$ These effects may result in a decreased production of red blood cells, white blood cells, and platelets.

We have previously studied the effects of organic solvents on blood cells after long term occupational exposure below the hygienic standards. Low dose

Department of Experimental Surgery, Thoracic Clinics

H Beving, P Olsson

Department of Thoracic Medicine, Karolinska Hospital, S-10401 Stockholm, Sweden

G Tornling exposure to organic solvents may cause a disturbed platelet function measured as the kinetic uptake of serotonin in platelets. ${ }^{6-7}$ In the second study workers were only exposed to organic solvents, in the first study they were also exposed to isocyanates. In both studies a higher rate of serotonin uptake was found.

The aim of this study was to investigate whether long term, low level occupational exposure to vapours of paints and organic solvents may cause changes in haematological parameters such as cell counts and cell volumes in peripheral venous blood from car repair painters and mechanics.

\section{Materials and methods}

The study population consisted of 17 car repair painters (age range 24-60) and 28 car mechanics (age range 22-54) who took part in a health survey on car repair workers. Only those who did not report any symptoms or diseases that could affect haematological parameters were included. The control group consisted of 40 healthy male office workers (age range 2166 ), who were not occupationally exposed to organic solvent or to hazardous chemicals.

The organic solvents used were toluene, xylene, white spirit, butanol, methyl isobutylketone, isopropanol, butyl acetate, and ethyl acetate. The car repair workers' current exposure to organic solvents was below the Swedish threshold limit values according to measurements carried out by the Motor Industry's Organisation for Working Environment, Safety and Health (Motorhälsan), Stockholm.

The subjects who volunteered for blood sampling were selected at random and they participated in the study with informed consent. The exposed and control groups were similar with respect to general health and background variables such as intake of alcohol and tobacco habits.

Intake of drugs, such as acetylsalicylic acid, steroids, and $\beta$-blockers, were not allowed later than 10 days before blood sampling, which was performed in the middle of an ordinary working week. The blood was collected in glass test tubes (Vacutainer No $606452 ; 5 \mathrm{ml}$ ) containing tripotassiumethylenediaminetetra-acetate (K3EDTA; $0.060 \mathrm{ml}$ $0.34 \mathrm{~mol} / 1 \mathrm{EDTA} ; 15 \% \mathrm{w} / \mathrm{w})$. Before measurement 
of haematological parameters the blood samples were kept at room temperature for one hour, and the test tubes were then rotated end to end for 10 minutes at $15 \mathrm{rpm}$. The blood samples were diluted 1:40 000 for erythrocyte and platelet analyses and 1:400 for the leucocyte analyses. Immediately after dilution the samples were analysed in an electronic cell counter (Contraves Analyzer 8016, Contraves Ltd, Zurich, Switzerland). The instrument performed cell counting in $2 \times 125$ channels, and the discrimination level was set automatically to minimise scattered background counting. The calibration of the instrument was checked by current analyses with control blood (Merz and Dade, Dudingen, Switzerland). No drift in the settings was detected during the time of the study. The measurements included leucocyte count (WBC), erythrocyte count (RBC), erythrocyte mean cellular volume (MCV), haematocrit (HCT), platelet count (PLT), and mean platelet volume (MPV). The mode in the volume distribution of erythrocytes (MAXRBC) and platelets (MAXPLT) - that is, the most frequent value of the cell volume-was also measured. Two measurements were performed and the mean was used as the sample value.

\section{STATISTICAL ANALYSIS}

Means and standard deviations were calculated and analyses of differences between the exposed group and the control group were performed with the MEANS procedure and the T-TEST procedure, SAS Institute Inc, Cary, NC, USA. ${ }^{8}$

\section{Results}

No significant differences in the cell counts and the cell volumes were detected between smokers and nonsmokers. Thus the smokers and the non-smokers were not separated in the calculations. None of the exposed workers complained about symptoms that could be related to exposure to solvents, and the intake of alcohol was low to moderate in all groups.

The table presents the results. The erythrocyte count (RBC) was significantly decreased for the painters $(p<0.05)$ and the mechanics $(p<0.001)$. The painters had increased $(p<0.001)$ mean eryth- rocyte volume (MVC) and the mode in the size distribution of erythrocytes (MAXRBC) was shifted towards larger cell volumes for painters $(p<0.05)$ and mechanics $(p<0.05)$ compared with controls. When data from the painters and the mechanics were combined, a significant increase in the mean platelet volume (MPV) was found $(\mathrm{p}<0.05)$.

\section{Discussion}

In this study we found haematological changes in both car repair painters and car mechanics. The mechanics were much less exposed to organic solvents than the painters but some exposure occurred, especially during cleaning of mechanical components. The groups were similar with respect to intake of alcohol and smoking habits, which can affect the haematological parameters. Exposed persons and controls may also differ, however, in other background variables such as physical activity, and general lifestyle.

The leucocyte count was similar in the exposed groups and in the control groups, although there was an indication that the value for the car painters was increased. Also the haematocrit values were on the same level in the investigated groups; both the car repair painters and mechanics had significantly reduced erythrocyte counts, but the reduction was larger for the mechanics. The erythrocyte volume was significantly increased in both of the exposed groups, but the increase was more pronounced for the painters. No significant differences were found between exposed persons and controls for platelet count or platelet volume. When data from car painters and mechanics were combined, significant differences between all exposed workers and unexposed controls were seen in erythrocyte count, erythrocyte volume, and platelet volume.

Car spray painters are exposed to several industrial organic hydrocarbons ${ }^{9}$ and car mechanics are also exposed to organic solvents during cleaning of engine parts. Earlier investigations on painters in Sweden, ${ }^{10}$ Finland, ${ }^{11}$ and Denmark ${ }^{12}$ have shown that their exposures are well below threshold limit values. Solvents used in car repair shops in the past con-

Haematological parameters for car repair spray painters, car mechanics, and control workers

\begin{tabular}{|c|c|c|c|c|}
\hline & $\begin{array}{l}\text { Painters } \\
(n=17)\end{array}$ & $\begin{array}{l}\text { Mechanics } \\
(n=28)\end{array}$ & $\begin{array}{l}\text { All exposed } \\
(n=45)\end{array}$ & $\begin{array}{l}\text { Controls } \\
(n=46)\end{array}$ \\
\hline $\begin{array}{l}\text { WBC }(\mathbf{k} / \mu \mathrm{l}) \\
\operatorname{RBC}(\mathbf{M} / \mu \mathrm{l}) \\
\operatorname{HCT}(\%) \\
\operatorname{MCV}(\mathrm{fl}) \\
\operatorname{MAXRBC}(\mathrm{fl}) \\
\operatorname{PLT}(\mathbf{k} / \mu \mathrm{l}) \\
\operatorname{MPV}(\mathrm{fl}) \\
\operatorname{MAXPLT}(\mathbf{f l})\end{array}$ & $\begin{array}{cl}6.6 & (1 \cdot 8) \\
4 \cdot 23 & (0 \cdot 3)^{\star} \\
42 \cdot 4 & (3 \cdot 4) \\
101 \cdot 0 & (7 \cdot 5)^{\star \star \star} \\
84.4 & (4 \cdot 5)^{\star} \\
223 & (39) \\
7.0 & (0.4) \\
4 \cdot 2 & (0.3)\end{array}$ & $\begin{array}{cl}5.9 & (2.1) \\
4.08 & (0.2)^{\star \star \star} \\
40.2 & (3.5) \\
98.5 & (7.5) \\
83.6 & (3.6)^{\star} \\
195 \quad(55) & \\
7.2 & (0.4) \\
5.8 & (0.9)\end{array}$ & $\begin{array}{cl}6.2 & (1.9) \\
4.13 & (0.3)^{\star} \\
41.0 & (3.6) \\
99.5 & (7.5)^{\star} \\
83.9 & (3.9)^{\star} \\
206 & (51) \\
7.1 & (0.4)^{\star} \\
5.8 & (0.9)\end{array}$ & $\begin{array}{cc}5.6 & (1.7) \\
4.43 & (0.5) \\
40.3 & (4.2) \\
91.2 & (4.8) \\
81.6 & (4.9) \\
208 & (35) \\
6.9 & (0.5) \\
5.5 & (0.7)\end{array}$ \\
\hline
\end{tabular}

${ }^{\star} \mathrm{p}<0.05 ;{ }^{\star \star \star} \mathrm{p}<0.001$; statistically different from control values. Results are means (SD). 
tained impurities of benzene. In Sweden the use of benzene has been forbidden since 1972, and it is reasonable to assume that the workers in this study have not been exposed to benzene during recent years.

Our results show that some haematological parameters measured in peripheral venous blood from car repair painters and car mechanics differ significantly from control values. The data from our haematological measurements accord with the results of Bättig et $a l^{13}$ who found hyperchromic red blood cells in workers exposed to trimethyl benzene and our earlier results, which showed that low level exposure to vapours of epoxy paints increased mean platelet volume, reduced red cell counts, and increased haematocrit values. ${ }^{14}$ On the other hand Elofsson $e t a l^{10}$ and Ørbaeck et $a l^{15}$ found increased haematocrit values and erythrocyte counts in blood samples from car spray painters. The reason for this discrepancy is unclear, but may be due to differences in the composition of the paints.

We have reported changes in the function of platelets from car spray painters and graphic workers with high exposure to aromatic solvents. ${ }^{67}$ An increase in platelet volume, however, due to exposure to solvents has to the best of our knowledge not been reported before. Contrary to these results blood samples taken from thermoplastic industry workers exposed to chemicals and solvents, showed reduced erythrocyte and platelet volumes. ${ }^{16}$

These observations indicate that the effects on the blood cells can vary with the type of chemical exposure. We think that the major differences in haematological data between the car repair painters and mechanics and the control group in this study may be due to exposure to organic solvents, although the results must be confirmed in other groups similarly exposed.

The present data do not allow us to say whether the observations reflect effects of short term or long term exposure or whether they are reversible after reducing the exposure. The results suggest that measurements of exposure in combination with haematological analyses may detect early adverse effects. The clinical significance of the changes remains unclear.
This study was supported by grants from the Swedish Work Environment Fund and the Karolinska Institute, Stockholm, Sweden. We thank Urban Olsson for linguistic revision of the manuscript.

1 Baker EL Jr, Smith TJ, Landrigan PJ. The neurotoxicity of Industrial solvents: A review of the literature. $A m \mathrm{~J}$ Ind Med 1985;8:207-17.

2 Levy BS, Wegman DH. Occupational Health. Recognizing and preventing work-related disease. Boston: Little Brown and Co, 1983:317-30.

3 Parmeggiani L, ed. Encyclopedia of Occupational Health and Safety. Vol 2. 3rd ed. Geneva: International Labour Office, 1983.

4 Aksoy M. Benzene as a leukaemogenic and carcinogenic agent. Am J Ind Med 1985;8:9-20.

5 Cronkite EP, Drew RT, Inoue T, Bullis JE. Benzene hematotoxicity and leukemogensis. Am J Ind Med 1985;7:447-56.

6 Beving H, Malmgren R, Olsson P, Tornling G, Unge G. Increased uptake of serotonin in platelets from car spray painters occupationally exposed to mixtures of solvents and organic isocyanates. Scand J Work Environ Health 1983;9:253-8.

7 Beving H, Kristensson J, Malmgren R, Olsson P, Unge G. Effect on the uptake kinetics of serotonin (5-hydroxy-tryptamine) in platelets from workers with long-term exposure to organic solvents. Scand J Work Environ Health 1984;10:229-34.

8 Cody RP, Smith JK. Applied statistics and the SAS programming language. New York: North Holland, 1985.

9 Chatterjee DS. A health survey of car painters of different ethnic origin and the importance of racial factor. J Occup Med 1984;34:86-89.

10 Elofsson S-A, Gamberale F, Hindmarsh T, et al. Exposure to organic solvents: A cross-sectional epidemiologic investigation on occupationally exposed car and industrial spray painters with special reference to the nervous system. Scand J Work Environ Health 1980;6:239-73.

11 Kurppa K, Husman K. Car painters exposure to a mixture of organic solvents. Scand J Work Environ Health 1982;8: $137-40$.

12 Pedersen LM, Rasmussen JM. The haematological and biochemical pattern in occupational organic solvent poisoning and exposure. Int Arch Occup Environ Health 1982;51:113-26.

13 Bättig K, Grandjean E, Turian V. Gesundheitsschäden nach langdauerder Trimethylbenzol-Exposition in einer Malerwerkstatt. Zeitschrift fur Präventivmed 1956;1:389-403.

14 Beving H, Malmgren R, Petrén S, Vesterberg O. Haematological changes in house painters using epoxy paints. J Soc Occup Med 1991:41 (in press).

15 Ørbaeck P, Risberg J, Rosén I, et al. Effects of long-term exposure to solvents in the paint industry. A cross-sectional epidemiological study with clinical and laboratory methods. Scand J Work Environ Health 1985;11(suppl 2):1-28.

16 Beving $\mathrm{H}$, Petrén $\mathrm{S}$, Vesterberg $\mathrm{O}$. Increased isotransferrin ratio and reduced erythrocyte and platelet volumes in blood from thermoplastic industry workers. Ann Occup Hyg 1990;34: 391-7.

Accepted 14 January 1991 